\title{
Doğal Olayların Tetiklediği KBRN-p Tehlikesi ve Riski: Türkiye Örneği
}

\author{
Ayşe Handan Dökmeci ${ }^{1 *} \oplus$, Öznur Akduman² ${ }^{2}$ \\ 1,2Tekirdağ Namık Kemal Üniversitesi, Sağlık Yüksekokulu, Acil Yardım ve Afet Yönetimi Anabilim Dalı, 59000, Tekirdağ.

\section{Özet}

Jeostratejik konumu ve küresel iklim değişikliği nedeniyle ülkemizde son 10 yıldır doğal olaylar daha sık ve șiddetli yaşanmaktadır. Doğa kökenli olayların tetiklemesiyle birlikte ardışık etkilerle ortaya çıkabilecek büyük ölçekli Kimyasal, Biyolojik, Radyolojik, Nükleer ve Patlayıcı (KBRN-p) felaketlerin gerçekleșme olasılığı genellikle düsüktür. Ancak, insanlar, çevre, altyapı, belirli alanların ekonomisi ya da tüm bölge/ülke üzerinde potansiyel etkileri yüksek olmaktadır. Ülkemizde deprem, sel, heyelan ve çı̆̆gibi doğa kökenli olaylara yönelik haritalar bulunmaktadır. Fakat KBRN-p tehlikelerine yönelik hazırlanmış haritalar bulunmamaktadır. İklim değişikliğinin, hava ile ilgili doğal tehlikelerin sılkı̆ğnı ve yoğunluğunu artırdiğı düşünüldüğ̈̈nde mevcut KBRN-p maddelerinden kaynaklanabilecek tehlikelerin envanterinin bilinmesi risklerin azaltılmasında ve olası faciayı önlemede kilit rol oynayabileceği düşünülmektedir. Çalışmamızda ardışık afet kavramı ve ardışık afetlerden kaynaklanabilecek KBRN-p tehlike ve riskler ele alınmıştır. Ayrıca KBRN-p olaylarının gerçekleşme olasılığl bulunan illerdeki endüstrileri ve enerji tesislerini içeren haritalar, T.C. Içişleri Bakanlığl Afet ve Acil Durum Yönetimi Başkanlı̆̆l (AFAD) tarafindan oluşturulmuş deprem, sel/su basması, heyelan ve çığ tehlike haritaları üzerinde örtüştürülerek hazırlanmış ve ardışı etkiler sonucu açı̆̆a çıkabilecek riskler literatür taramasına dayandırılarak değerlendirilmiştir. Bu değerlendirme sonucunda, doğal olaylar ile KBRN-p olaylarının karşılıklı bağımlılıkları; güvenlik açıklarının azaltılması, dirençliliğin artırılması, ikincil afetlerin değerlendirilmesi ve kritik altyapılarda risk azaltma uygulamaları gibi kritik adımların ele alınması gerektiği ve risk değerlendirmesi yaparken karşılıklı etkileşen, birleşik, birbirine bağll, ardışık tehlikelerin oluşturacağ risklerin göz ardı edilmemesi gerekliliği ortaya konmuştur. Çalışmamızın, ülkemizdeki doğa kökenli olayların tetikleyebileceği KBRN-p olaylarının ardışık afete dönüşmesini önlemede literatüre katkı săglaması ve KBRN-p tehlike ve risk haritalarının hazırlanmasında yol gösterici olması beklenmektedir.

\section{Anahtar Sözcükler}

Ardışık Afetler, KBRN-p, Doğal Kaynaklı Afetler, Risk, Türkiye

\section{CBRN-p Hazards and Risks Triggered by Natural Events; Turkey Example}

\begin{abstract}
Due to its geostrategic location and global climate change, natural events have been experienced more frequently and severely in the last 10 years in our country. The probability of large-scale Chemical, Biological, Radiological, Nuclear and Explosive (CBRN-p) disasters that may occur with sequential effects, triggered by natural events, is generally low. However, the potential impacts on people, the environment, infrastructure, the economy of certain areas or the entire region/country are high. There are maps for natural events such as earthquakes, floods, landslides and avalanches in our country. However, there are no maps prepared for CBRN-p hazards. Considering that climate change increases the frequency and intensity of natural hazards related to weather, it is thought that knowing the inventory of hazards that may arise from existing CBRN-p substances can play a key role in reducing risks and preventing possible disasters. In our study, the concept of sequential disaster and CBRN-p hazards and risks that may arise from sequential disasters are discussed. In addition, maps containing industries and energy facilities in provinces where CBRN-p events are likely to occur, T.C. The earthquake, flood/flood, landslide and avalanche hazard maps created by the Ministry of Interior Disaster and Emergency Management Presidency (AFAD) were prepared by overlapping, and the risks that may arise as a result of sequential effects were evaluated based on the literature review. As a result of this evaluation, the interdependence of natural events and CBRN-p events; It has been revealed that critical steps such as reducing vulnerabilities, increasing resilience, assessing secondary disasters and risk reduction practices in critical infrastructures should be addressed, and the risks posed by mutually interacting, combined, interconnected and sequential hazards should not be ignored when making risk assessments. It is expected that our study will contribute to the literature in preventing CBRN-p events, which may be triggered by natural events in our country, from turning into sequential disasters, and will guide the preparation of CBRN-p hazard and risk maps.
\end{abstract}

$\underline{\text { Keywords }}$

Cascade Disasters, CBRN-e, Natural Disasters, Risk, Turkey

\section{Giriş}

Teknolojik ve KBRN-p olayları dünya çapında hızla artan sanayileşme ve iklim değişikliği nedeniyle daha sık meydana gelmektedir. Dünya genelinde iklim değişikliğine bağlı doğa kökenli olayların sayısının ve şiddetinin artmasıyla afetlerin tetiklediği teknolojik/KBRN-p olaylar birbiriyle bağlantılı ve ardışık yeni riskler açı̆̆a çıkarmaktadır. 
Aslında 2011 Tohoku depremi ile birlikte "ardışık afet" kavramı bilim insanları ve uygulayıcılar arasında yaygın olarak kullanılmaya başlanarak domino taşlarının devrilmesi metaforuyla ilişkilendirilen bir kavram olarak gündeme gelmiştir (IFRC 2020). Ardışık ve karmaşık tehlikeler ile riskleri sistematik bir şekilde daha iyi tanımlamak ve anlamak için doğal, teknolojik ve diğer insan kaynaklı tehlikelerin doğrudan ve dolaylı bağlantılarını ve etkilerini araştırmaya ihtiyaç bulunmaktadır. Bu sebeple pek çok ulusal ve yerel otorite artık çoklu risk yönetişimi için çerçeveler geliştirmektedir (EU 2021). KBRN-p olayları, teknolojik veya endüstriyel koşullardan, tehlikeli prosedürlerden, altyapı arızalarından veya belirli insan faaliyetlerinden kaynaklanabileceği gibi afet boyutundaki bir olayın tetiklemesiyle beklenmedik ikincil olaylar şeklinde asıl olay kadar ciddi olma eğilimindedir ve afetin etkilerinin genel süresine önemli ölçüde katkıda bulunmaktadır. KBRN-p kaynaklı acil durumlar genellikle patlayıcıların, yakıcı ve yanıcı maddelerin, zehirlerin ve radyoaktif malzemelerin kullanımı ve depolanmasında meydana gelmektedir. Bu nedenle KBRN olay yönetiminde, çoklu tehlike yaklaşımına (doğal, teknolojik, sağlık, ekonomik, ekolojik, sosyal vb.) dayalı olarak genel riskler belirlenmeli ve potansiyel tehlike ve kırılganlık etkileşimleri hesaba katılmalıdır (Dökmeci 2018).

Çalışmada doğa kökenli/ kaynaklı olaylar ile KBRN-p olaylarının karşılıklı etkileşimleri ardışık afetlerin birer domino taşını oluşturduğundan, oluşabilecek riskleri azaltmaya yönelik; Büyük Endüstriyel Kazaların Önlenmesi ve Etkilerinin Azaltılması Hakkında Yönetmelik (BEKRA 2019) kapsamında yer alan alt ve üst seviye kuruluşların yer aldığı illerdeki doğa kaynaklı afet potansiyeli ile doğa kaynaklı afetlerin tetiklemesiyle ortaya çıkabilecek KBRN-p tehlike ve riskler ele alınarak risk azaltmaya yönelik çözüm önerileri sunulmuştur.

\section{Ardışık Afetler}

Ardışık afetleri anlamak için öncelikle afetin tanımını ve nasıl ortaya çıktığını bilmek gerekir. Afetler; insanlar için fiziksel, sosyal ve ekonomik zararlar doğuran, hayatı durduran veya sekteye uğratan, eldeki imkanları yetersiz bırakan doğal, teknolojik, insan kaynaklı ya da bu kaynakların bir veya birkaçının sebep olduğu olayların sonuçlarıdır (Kadıoğlu 2011). Şekil 1'de görüldüğü gibi tehlike, risk, acil durum, afet, ardışık afetler, karmaşık afetler ve katastrofik etkiler gibi tanımları birbirinden ayıran ana faktör zarar görebilirlik ölçeğidir. Zarar görebilirlik kavramı ise; herhangi bir olayın fiziksel büyüklüğü, hızlı nüfus artışı, olayın yerleşim alanlarına uzaklığı, riskli bölgelerdeki hızlı ve kontrolsüz şehirleşme ve sanayileşme, bilgisizlik ve eğitim eksikliği, ormanların ve çevrenin tahribatı veya yanlış kullanımı, toplumun afet olaylarına karşı önceden alabildiği koruyucu, önleyici ve risk azaltıcı önlemlerin etkinliklerine bağlıdır. Tüm bu faktörlere bağlı olarak yaşanılan herhangi bir olumsuz olay bir bölgede afet oluştururken, başka bir bölgede acil durum olarak ya da daha da etkisiz bir olay olarak algılanmaktadır (Ergünay 2009).

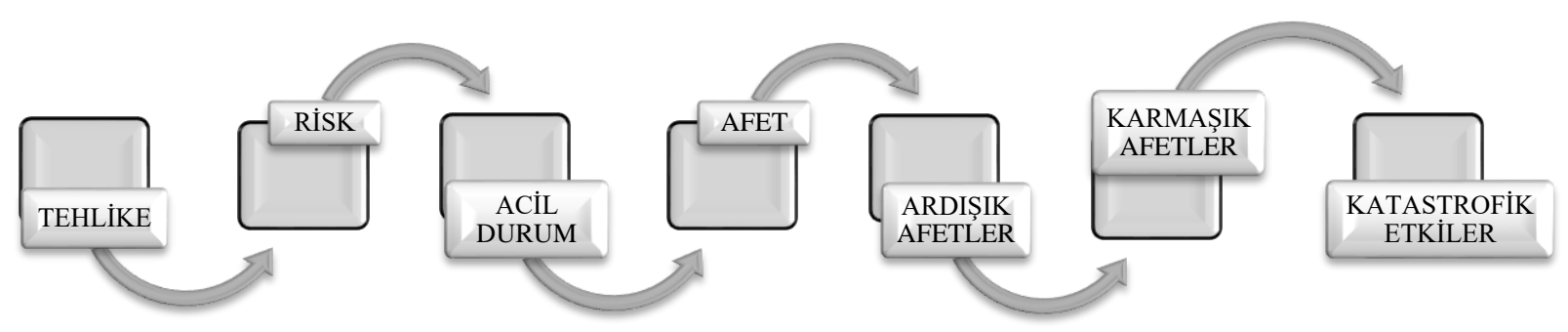

\section{ZARAR GÖREBILLIRLIK}

\section{Şekil 1: Toplumsal zarar görebilirlik artıkça değişen tanımlamalar}

Boin vd. (2018) afeti "bir şekilde ortaya çıkan ve varoluşa yönelik algılanan tehdittir" şeklinde tanımlamışlardır. Bu algılanan tehdide yönelik yapılan önleme/hafifletme, hazırlık, müdahale ve iyileştirme bileşenlerinin tümüyse bütünleşik afet yönetimini oluşturmaktadır (Boin vd. 2018). Afet yönetimi toplumsal savunmasızlıkları, riskleri, tehditleri, tetikleyicileri, süreçleri, yanıtları ve sonuçları bir araya getiren ve süreklilik arz eden bir döngüdür. Bu döngüyü oluşturan afet çeşitleri farklılık gösterse de temel özellikleri aynıdır. Bu temel özellikler ise tehditler, belirsizlik ve acil müdahale gerekliliğidir (Donaldson 1991). Tarih boyunca art arda yaşanan afetler 21. yüzyılda savunmasızlığın ve güvenlik açıklarının da artması ile evrim geçirmiş ve ardışık afetler olarak yeni bir boyut kazanmıştır (Quarantelli 2005). Ardışık kelimesi birbiri ardından gelen anlamına gelmektedir (TDK 2015). Ardışık etki ise Şekil 2'de görüldüğü gibi bir sistemi etkileyen bir eylem nedeniyle kaçınılmaz ve bazen öngörülemeyen olaylar zinciridir. Buna ek olarak ardışı etkilerin zamanla artarak, beklenmedik bir zamanda, güçlü etkilere sahip başka olumsuz olayların artması ile oluşan aşırı olaylar zinciri ise ardışık afetlerdir (Alexander ve Pescaroli 2019). 


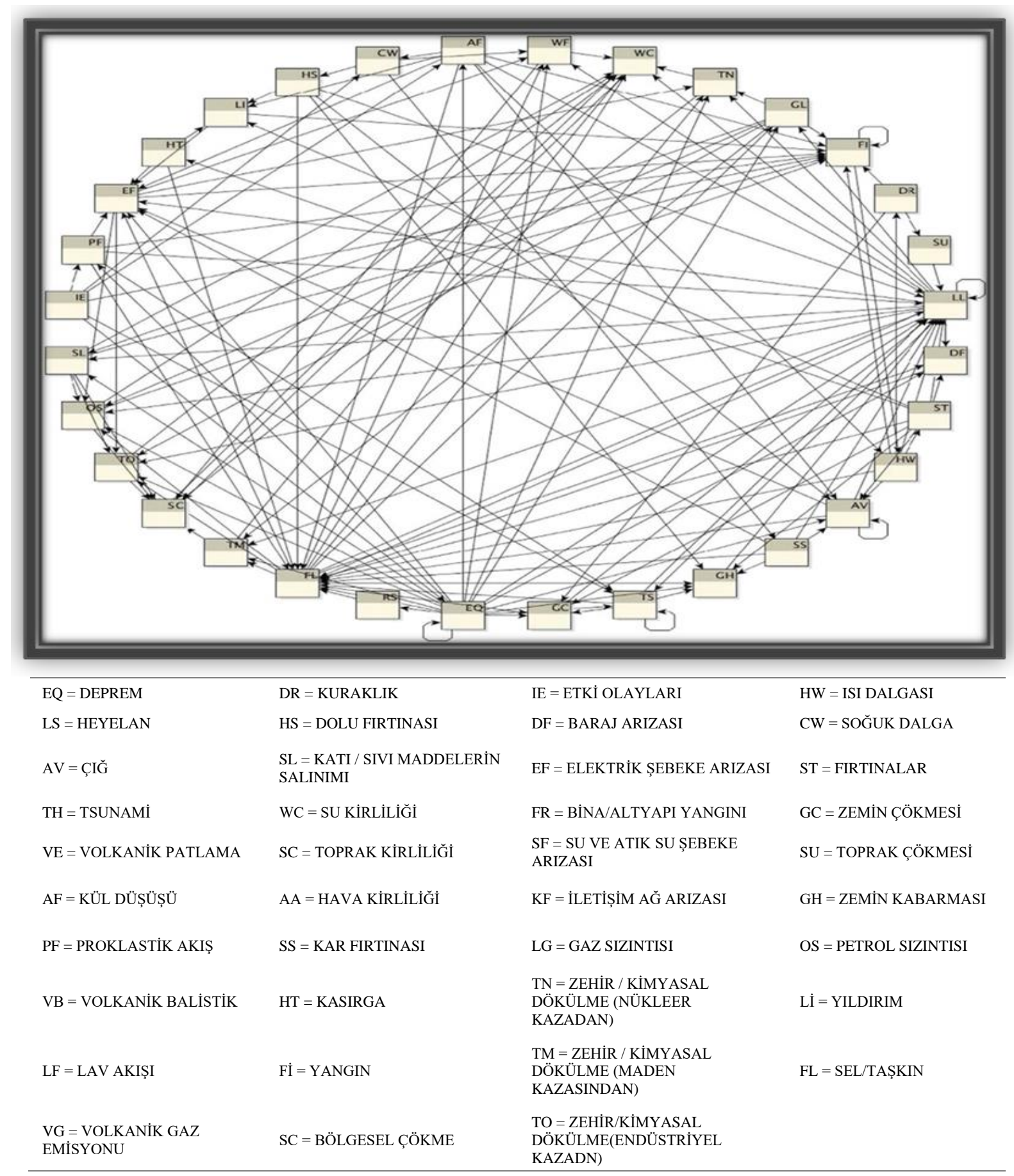

Şekil 2: Tehlike uyumluluk matrisine dayanan tehlikeler arasındaki tüm potansiyel bağımlılıkları gösteren diyagram ve tehlike uyumluluk matrisi harita bilgisi (Zuccaro vd. 2018)

Esas olarak bir felaket olayı tek başına gerçekleşmez. Şekil 2'de verilen bilgilere göre çoğu felaket olayı genellikle sıralı reaksiyonları tetikler ve böylece daha büyük kayıplara neden olur (Zuccaro vd. 2018). Ardışık afetler, afetlerin tek bir birincil tehditle başlaması ve daha sonra olay dizileri şeklinde ortaya çıkmasıdır (May 2007). Bu süreçte yaşanılan durum ardışık afetlerin meydana gelme sürecidir (Pescaroli ve Alexander 2019). Bir başka ifadeyle de toplumda yaşanmakta olan herhangi bir afetin sonuçlarının, başka bir afetin nedeni veya nedenlerinden biri olarak karşımıza çıkmasıdır.

Ardışık afetler/krizler/acil durumlar, birincil (tetikleyici) etkiyle domino taşlarının devrilmesi metaforu gibi zincirleme etkiler oluşturan, fiziksel ve sosyal savunmasızlık arasında bağlantısı olan, bileşik ve birbirine bağlı riskler ile karmaşık etkileşimli güvenlik açıkları barındıran, kritik altyapı üzerindeki karmaşık etkiler oluşturan, doğrusal olmayan ilerleme ve risklerin ciddiyetini artıran, çoklu ölçekli ve ikincil riskler oluşturan etkilere sahiptir. Bunlar, en az tetikleyen olay kadar ciddi olma ve afetin etkilerinin toplam süresine önemli ölçüde katkıda bulunma eğilimindedir (Pescaroli ve Alexander 2015). 


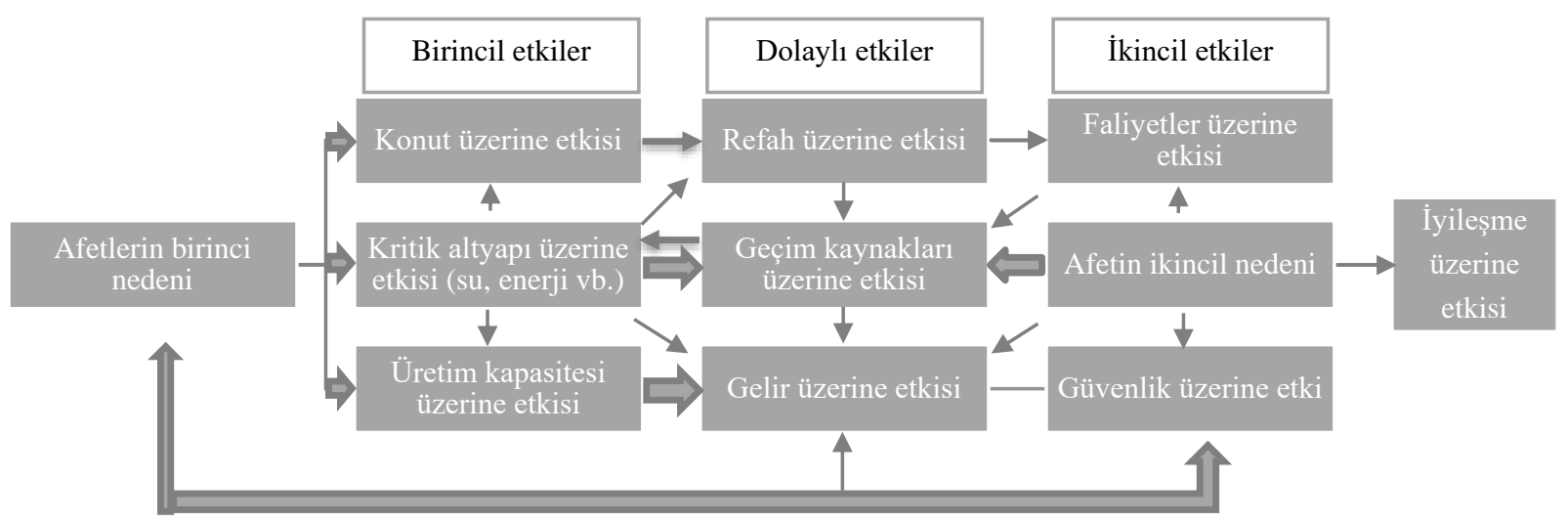

Şekil 3: Ardışık afetlerin etkileri (Pescaroli ve Kelman 2016)

Tetikleyen olay ile birlikte ardışık afetlerin basamaklarında gerçekleşen tetiklenen olaylar ülkelerin yanıt verme kapasitesini aşmasına ve kritik yapıların sekteye uğramasına neden olmaktadır (Alexander 2018) (Şekil 3). Düzensiz ve kontrolsüz endüstrileşme yaşanan bölgede, plansız yerleşim, altyapının yetersiz kalması ile yaşanan ani sel felaketi ve beraberinde yaşanan yangın/patlama olayları sonucu kritik alt yapı hasar görmektedir. Meydana gelen tehlikeli madde sızıntısı nedeniyle de çevresel kontaminasyon ve tahliye süreci ardışık afet döngüsünü oluşturan tehlike ve riskleri oluşturmaktadır (Şekil 4). Bu örnekte de görüldüğü gibi gerekli önlemler alınmazsa ardışık ve zincirleme olaylar her an karşılaşabileceğimiz, beklenmedik ve topluma zarar verici durumlar oluşturmaya devam edecektir.

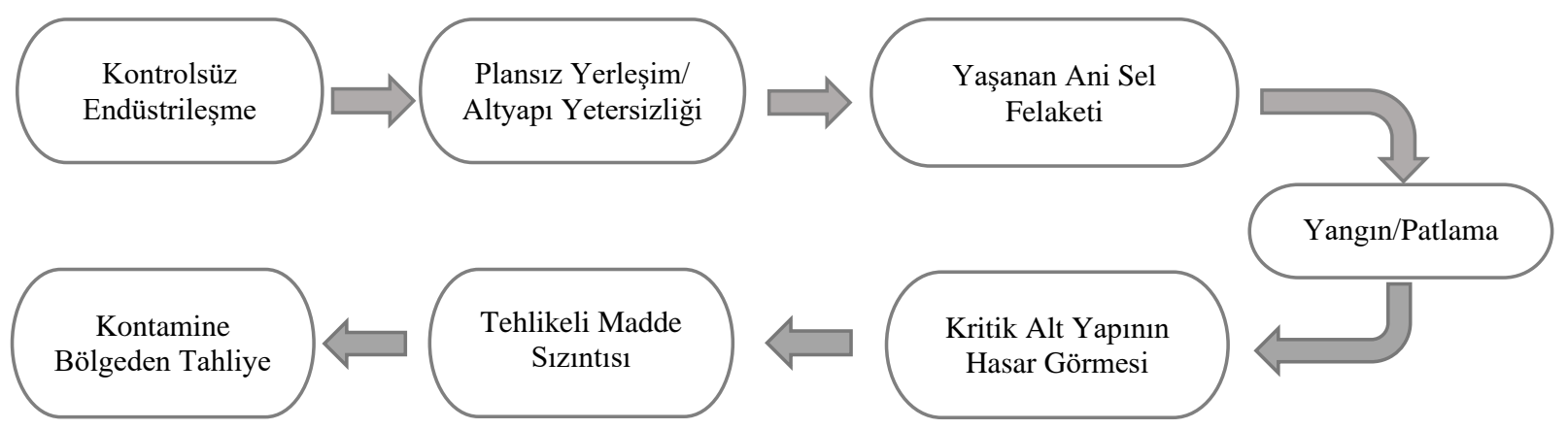

Şekil 4: Ardışık afet döngüsü örneği

\section{Doğal Kaynaklı Afetlerin Tetiklediği KBRN-p Tehlike ve Riskler}

Doğal kaynaklı afetler teknolojik tehlikeleri tetikleyerek bileşik veya ardışık afetlere neden olabilmektedir. Afetler için temel kavramsal denkleme baktığımızda tehlike sonucunda bir etki oluşurken, ardışık afetlerde önemli ölçüde daha karmaşık ve genişletilmiş etki olduğu görülmektedir (Şekil 5).

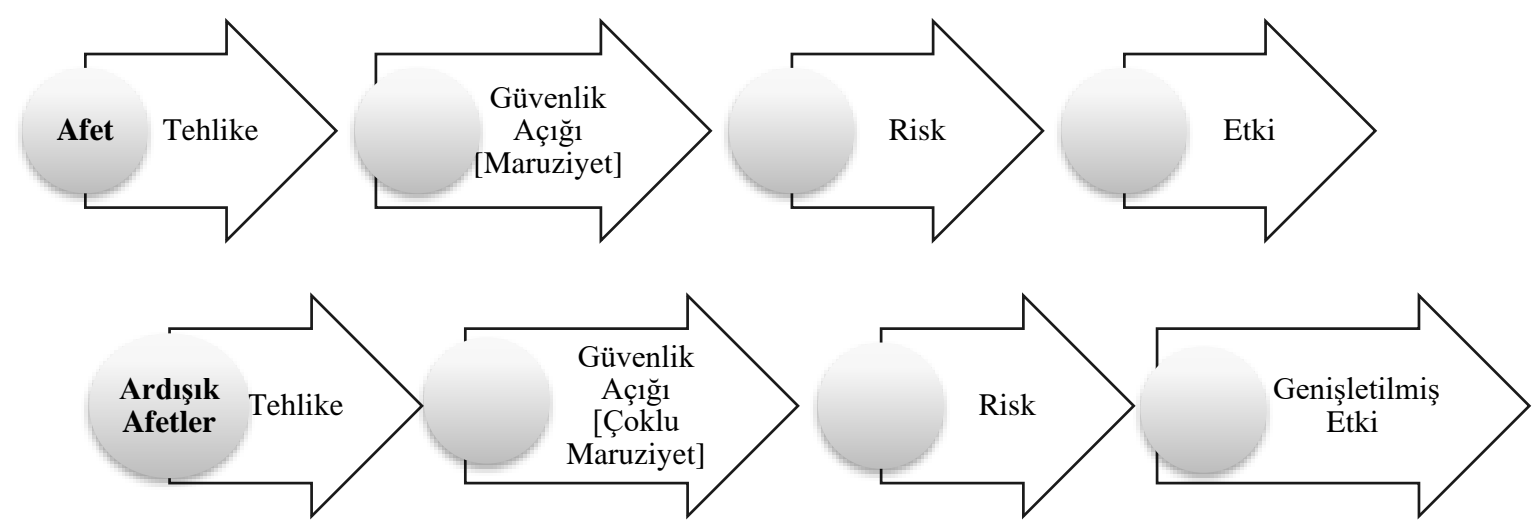

Şekil 5: Afetler ve ardışık afetlerin kavramsal denklemi (Alexander 2018)

Bir bölgede gelecekteki bir zaman diliminde tehlikeli bir olayın meydana gelme olasıllğı ve etkileri (kayıp ve/veya hasar) risk olarak tanımlanmaktadır. UN/ISDR (2004), risk kavramını doğal veya insan kaynaklı tehlikeler ile hassas koşullar arasındaki etkileşimlerden kaynaklanan zararlı sonuçların olasılığı olarak tanımlar. 
Dikkat gerektiren iki husus vardır. Bunlar; sosyal faktörlerin risk üzerindeki etkisi ve tehlike yoğunluğu ve dağılımının tahminidir. Afet riski ise sürekli olarak mevcut risk koşullarının sonucu olarak tehlikeli olaylar ve afetler kavramını yansıtır. Buna ek olarak afet riski, genellikle sayısallaştırılması zor olan farklı potansiyel kayıp türlerini içerir. Bununla birlikte, mevcut tehlikeler ve nüfus ve sosyoekonomik gelişme kalıpları hakkında bilgi sahibi olarak, afet riskleri geniş anlamda değerlendirilebilir ve haritalandırılabilir (UNDRR 2021a). Bu tanımdan yola çıkarak bu çalışmada ülkemizdeki doğal kaynaklı olay haritaları üzerinden mevcut KBRN-p tehlikeleri değerlendirilerek yeni tehlike haritaları oluşturulmuştur.

Natech olayları olarak da bilinen, doğal olayların tetiklediği, aynı anda veya birbirini takip eden kısa süre içinde meydana gelen bileşik ve/veya ardışık etkiler oluşturan tehlikeli teknolojik olaylar; doğal, teknolojik, sağlık, ekonomik, ekolojik, sosyal vb. etkiler oluşturarak toplumları tehdit etmektedir (IFRC 2020). Aslında doğal olayların tetiklediği KBRN-p olayları da natech olayı olarak değerlendirilebilir. Doğal kaynaklı olayların tetiklediği ardışık afetler sonucu ortaya çıkan KBRN-p tehlike ve risklere en gerçek örnek; 11 Mart 2011 tarihinde yaşanılan Tohoku depremidir. Ardışık olarak yaşanan deprem, tsunami ve nükleer santral kazası sonucu yaklaşık 18000 kişi hayatını kaybetmiş ve büyük bir çevre felaketi yaşanmıştır. Yaşanan akut etkilerin dışında radyoaktif kirlenmenin kronik etkileri ise halen devam etmektedir (Dökmeci 2018). Bir diğer örnek ise Türkiye'nin sanayi üretiminin \%30'nun bulunduğu Kocaeli'nde 1999 y1lında 7,5 büyüklüğünde yaşanan deprem ve beraberinde ortaya çıkan ardış1k etkilerdir. Deprem sonucunda on dokuz endüstriyel tesisten 18'inde hasar, 14 tesiste tehlikeli madde salınımı (İzmit Körfezi'ne 50 ton ham petrol salınımı, 1200 ton kriyojenik oksijen salınımı, 100 ton fosforik asit dökülmesi, 30 ton sülfürik asit dökülmesi), toplam 21 tehlikeli madde olayı ve 21 petrol rafinerisinde eşzamanlı üç bağımsız yangın gerçekleşmiştir (Cruz 2003). Bu örneklerden de anlaşılacağ1 üzere doğal kaynaklı afetlerin olası ardışık etkileri tehlikeli maddelerin salınımı, yangınlar ve patlamalar gibi ikincil afetlere neden olarak insan ve çevre sağlığı, sosyo-ekonomik etkiler gibi istenmeyen sonuçlara neden olmaktadır.

Hükümetler afetlerin neden olduğu sosyal, ekonomik, çevresel ve sağlık kayıplarını azaltmak amacıyla, farklı sektör ve aktörlerden yapılması gereken çalışmaları tanımlayan 2005-2015 Hyogo eylem çerçevesini benimsemiştir (UNDRR 2007). Bu çerçeveyi, odak noktasını afetleri yönetmekten riskleri yönetmeye kaydıran 2015-2030 afet riskinin azaltılmasına yönelik Sendai çerçevesi izlemiştir (UNDRR 2015). Çerçeve, özellikle afet risk yönetimine entegre, tüm tehlikeler, çok sektörlü bir yaklaşıma duyulan ihtiyacı vurgularken KBRN-p risklerinin neden olduğu zorlukları da ele almaktadır. Ayrıca çerçeve ile birlikte ülkeler ulusal eylem planlarını uluslararası boyutta planlayarak, afetlerden kaynaklanacak olan kayıpları azaltabileceklerdir. Afet risklerine bütüncül yaklaşmak önem taşımaktadır. Bu nedenle doğal kaynaklı afetlerin tetiklediği KBRN-p tehlike ve risklerin birlikte değerlendirilmesi büyük önem taşımaktadır.

\section{Türkiye'nin Doğal Kaynaklı Afet ve KBRN-p Tehlike Potansiyeli}

Doğal kaynaklı afetlerin etkileri ülkelerin gelişmişlik seviyelerine ve olayın şiddetine göre değişiklik göstermektedir. Dünya genelinde iklim değişikliğine bağlı doğal kaynaklı afetlerin sayısı ve şiddeti her geçen yıl daha da artmaktadır. EM-DAT (2021) verilerine göre 2020 yılında 389 doğal afet yaşanmıştır. Yaşanan bu afetler 15.080 kişi hayatını kaybetmesine, 98,4 milyon kişinin etkilenmesine ve 171.3 milyar ABD Dolarına mal olmuştur. COVID 19 pandemisinin yanı sıra bahsedilen yıla iklimle ilgili afetler hakim olmuştur. 2020 yılında, güçlü bir El Nino etkisinin olmamasına rağmen dünyanın kaydedilen en sıcak yılı olarak 2016'ya rakip olmuştur. Önceki yirmi yıla (2000-2019) k1yasla 2020, kaydedilen olay sayısı ve ekonomik kayıplar (151,6 milyar ABD Doları) açısından daha yüksek bir etkiye sahip olmuştur (EM-DAT 2021). AFAD (2021) verilerine göre Türkiye'de ise, 2020 yılında 11 çı̆̆, 321 deprem, 107 heyelan,17 kaya düşmesi, 2 obruk, 177 sel/su baskını, 207 diğer olmak üzere toplam 905 doğa kaynaklı olay meydana gelmiştir (AFAD 2021).

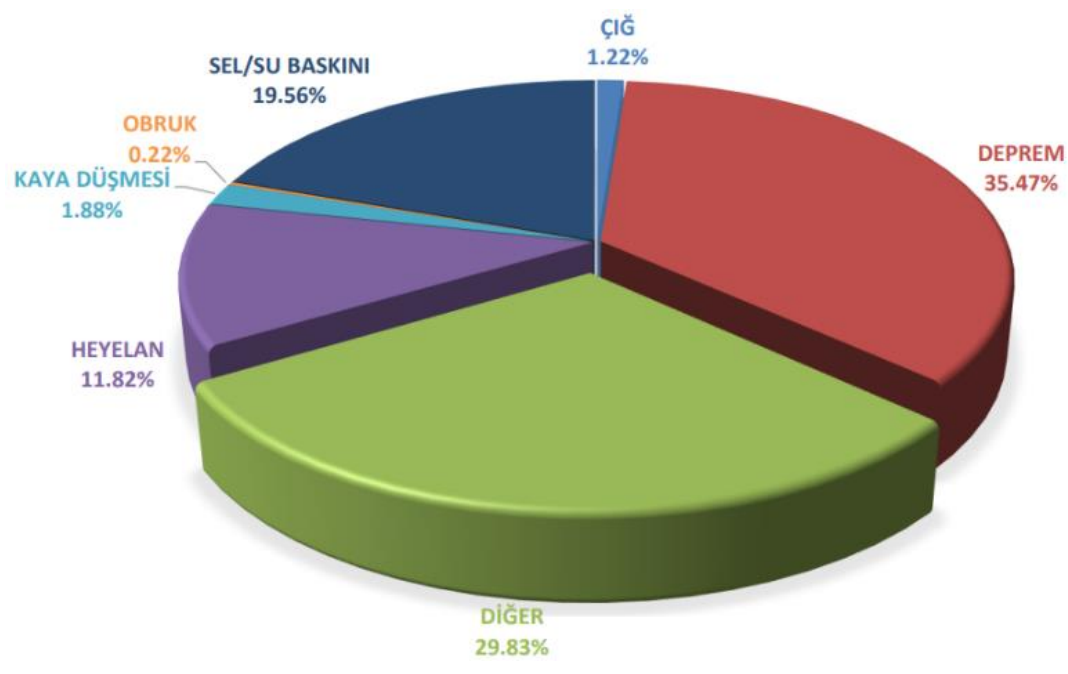

Şekil 6: Türkiye'de 2020 yılı doğa kaynaklı olay istatistikleri (AFAD 2021) 
Türkiye aktif volkanlar hariç, doğal kaynaklı afetlerin yaşandığı bir ülkedir. Başta kuraklık ve seller olmak üzere meteorolojik ve hidrolojik kaynaklı afetler sıkça meydana gelmekte ve ciddi can ve mal kayıplarına yol açmaktadır. Antik çağlardan beri tabletler, arkeolojik kazılar ve bunlardan elde edilen belgeler, Anadolu'nun M.Ö 2000 ile M.S 2000 y1lları aralığını kapsayan en uzun deprem kayıtlarına sahip olan bir bölge olduğunun kanıtıdır. Bununla birlikte bu doğal olayların tetikleyebileceği KBRN-p olayları ise ciddi tehdit oluşturmaktadır. Güncellenmiş ve birçok ayrıntılı veriyle hazırlanmış Türkiye Deprem Tehlike Haritasına göre ülkemizde deprem tehlikesi içeren bölgeler Şekil 7'de kırmızı ile gösterilmiştir (AFAD 2018). Haritadaki bilgilere göre ülkemizin yaklaşık \%66'lık bir kısmı yüksek deprem tehlikesi altındadır. İnsan yaşamı ve faaliyetlerinin devamlılığı için gerekli endüstrilerin deprem kuşağında yer alması çeşitli kimyasal, biyolojik, radyoaktif, nükleer ve patlayıcı riskleri beraberinde getirmektedir. Özellikle Kuzey Anadolu Deprem Kuşağı, Güneydoğu Anadolu Deprem Kuşağı ve Batı Anadolu Deprem Kuşağında yer alan petrol rafinerileri, LNG rafinerileri, kimyasal madde ve patlayıcı madde üretimi yapan alt ve üst seviyeli kuruluşlar şiddetli bir deprem sonrası önlem alınmazsa ardışık etkilerle yangın/patlama ve çevresel kontaminasyona neden olarak çevre ve halk sağlığ problemlerini beraberinde getirecektir. Ülkemizde yaşanan 17 Ağustos 1999 Kocaeli depremi sonrasında meydana gelen KBRN-p olaylarından dersler alınması ve hazırlanan acil durum planları ve risk analizlerinin dikkate alınması zarar azaltma ve dirençliliği artırmada önemli rol oynayacaktır. Ekonomik Kalkınma ve İşbirliği Örgütü (OECD) ülkeleri ve Avrupa Birliği (AB)'de endüstriyel tesislerde doğal tehlike ile tetiklenen kazalar için neredeyse hiç haritalandırma yapılmadığı tespit edilmiştir. Bu açığı kapatmak için depremlerden kaynaklanan endüstriyel kazalara yönelik olasılıksal bir risk haritalama metodolojisi geliştirilmiş (RAPID-N) ve web tabanlı bir yazılım aracı olarak uygulanmıştır (Girgin ve Krausmann 2013).

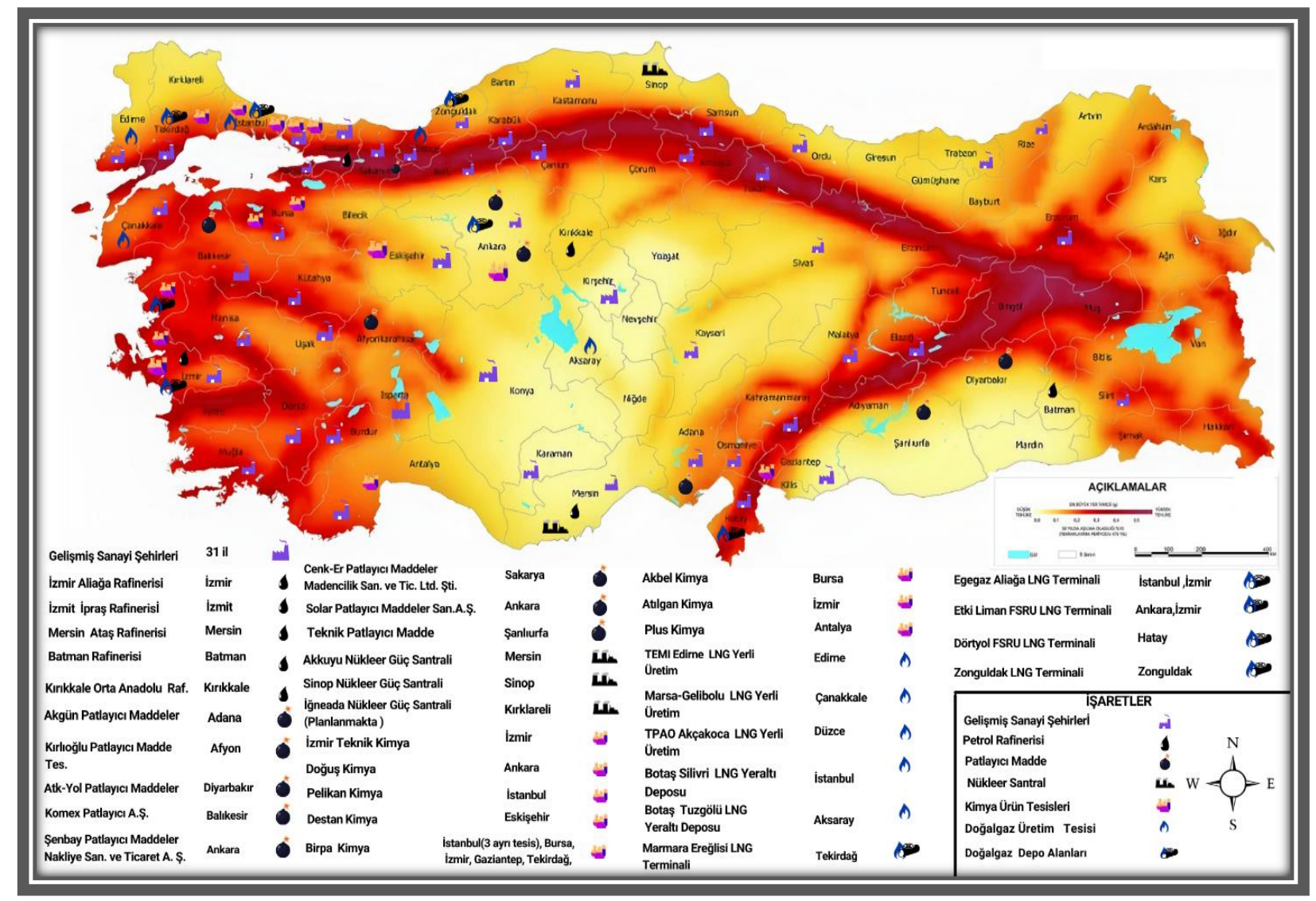

Şekil 7: Türkiye Deprem Tehlike Haritası (AFAD 2020) ve KBRN-p riski taşıyan endüstri ve enerji tesisleri

AFAD (2020), tarafından hazırlanmış olan Türkiye Sel ve Su Baskınları Tehlike Haritası, Ülkemizde 1950-2019 yılları arasında yaşanmış sel ve su baskını olaylarının verilerinin istatiksel modellemeleri sonucu oluşturulmuştur. Bu yıllar arası yaşanmış sel ve taşkın sayısı Şekil 8'de verilen haritada açık mavi renk ve koyu mavi renk arasındaki renk değişiklikleri ile açıtan koyuya doğru artan şekilde gösterilmiştir. 2019 yılında Ülkemizdeki sel ve su baskını sayısının il bazında dağılımı incelendiğinde; en yoğun illerin Samsun, Trabzon, Afyonkarahisar, Zonguldak, Aksaray, Hatay ve Eskişehir olduğu görülmektedir. Sel ve taşkın tehlikesinin olduğu bölgelerde KBRN-p açısından risk oluşturabilecek endüstri ve enerji tesisleri Şekil 9'da gösterilmiştir. Son 10 yılda küresel iklim değişikliğinin etkileriyle yurdun birçok yerinde sel ve su baskınları sayısı ve şiddeti hızla artmış olduğundan sel tehlike ve risk haritalarının güncellenmesi ve riskli bölgelerin tespiti olası ardışık etkilerin öncesinde alınacak önlemleri almada oldukça önemlidir. AFAD, afet duyarlılık ve tehlike haritalarının daha kolay ve hızlı bir şekilde, doğruya en yakın olarak hazırlanması, aynı platformda tutulması ve paylaşılması amacıyla web tabanlı Afet Risk Azaltma Sistemi’ni (ARAS) kurmuştur. 
ARAS; temel olarak heyelan, kaya düşmesi, çığ afetleri için duyarlılık ve tehlike analizlerinin gerçekleştirilebildiği ve söz konusu afetlere yönelik duyarlılık ve tehlike haritalarını üretilebildiği web tabanlı bir CBS (Coğrafi Bilgi Sistemleri) portalıdır. Ayrıca Su Yönetimi Genel Müdürlüğü tarafından hazırlanan taşkın risk haritaları ve taşkın tehlike haritaları sistem içerisinde yer almaktadır (AFAD 2020).

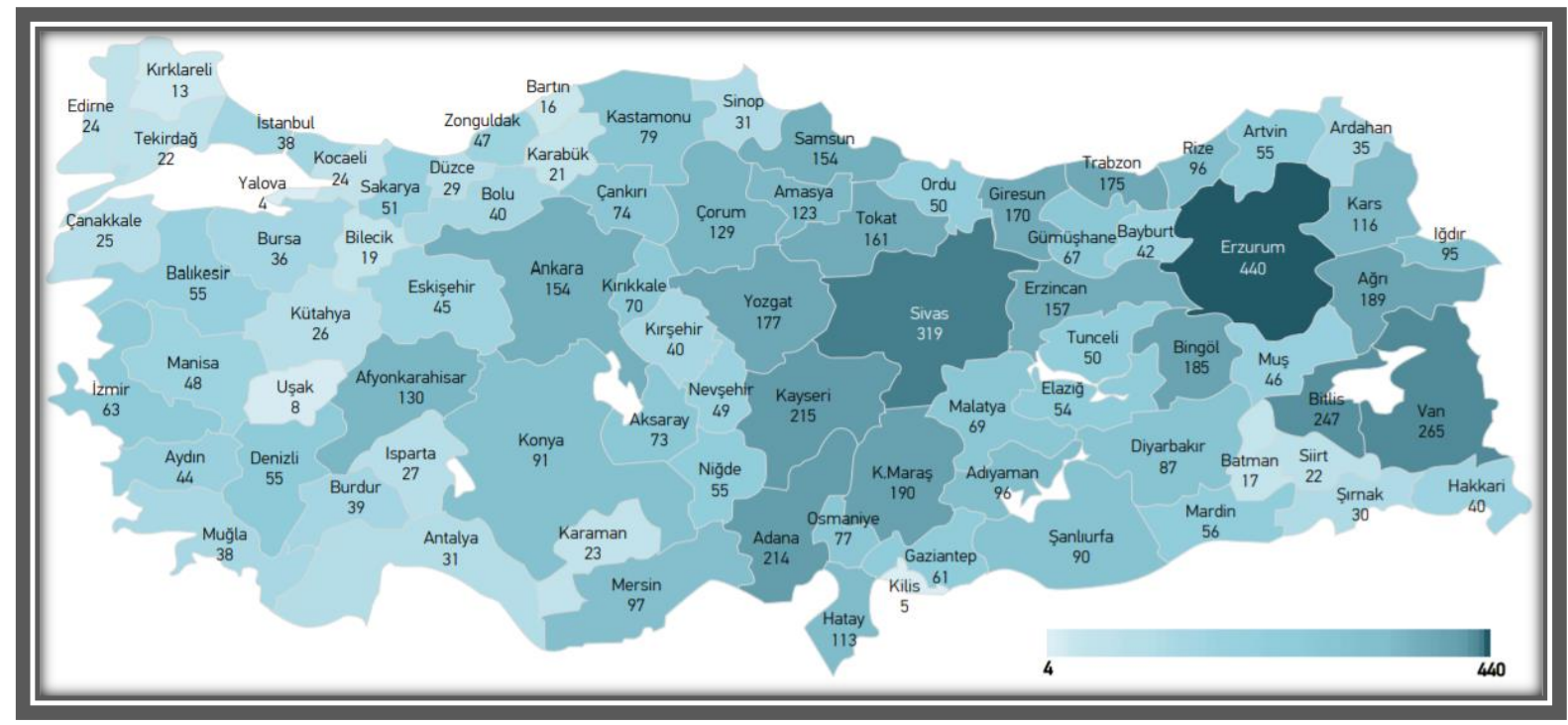

Şekil 8: 1950- 2019 yılları arasında Türkiye'de meydana gelen sel/su baskını olaylarının il bazında sayıları (AFAD 2020)

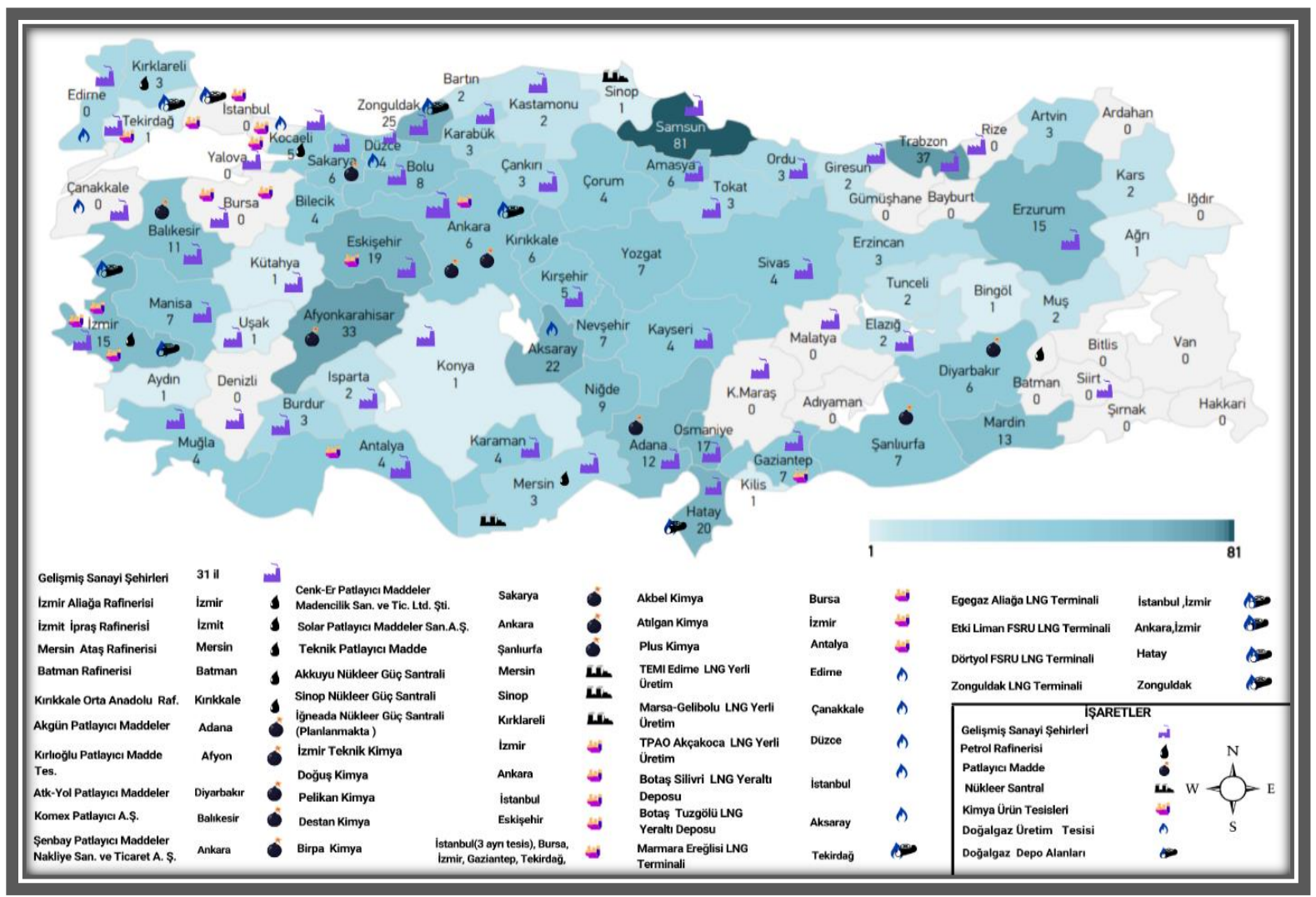

Şekil 9: 2019 yıllında Türkiye'de meydana gelen sel/su baskını olaylarının il bazında sayıları (AFAD 2020) ve KBRN-p riski taşıyan endüstri ve enerji tesisleri

AFAD (2020), tarafından hazırlanmış olan Türkiye Heyelan/Kaya Düşmesi Tehlike Haritası, Ülkemizde 1950-2019 yılları arasında yaşanmış heyelan/kaya düşmesi olaylarının verilerinin istatiksel modellemeleri sonucu oluşturulmuştur. $\mathrm{Bu}$ yıllar arası yaşanmış heyelan/kaya düşmesi sayısı Şekil 10'daki haritada beyaz ve siyah renk arasındaki renk değişiklikleri ile açıktan koyuya doğru artan şekilde gösterilmiştir. 2019 yılında İl bazında heyelan/kaya düşmesi sayısının dağılımı incelendiğinde; en yoğun yaşanan ilin Trabzon olduğu Zonguldak, Çorum, Mersin, İzmir, Kocaeli, İstanbul, Kahramanmaraş, Hakkâri ve Artvin illerinde de heyelan/kaya düşmesi riski bulunduğu görülmektedir. 
Heyelan/kaya düşmesi tehlikesinin olduğu bölgelerde muhtemel KBRN-p açısından risk oluşturabilecek endüstri ve enerji tesisleri Şekil 11'de gösterilmiştir. Karadeniz, sel ve heyelan gibi doğal afetlerin sık görüldüğü bir bölgedir. Bölgenin topografik ve jeolojik yapısı, aşırı yağışlar bu tür doğal olayların oluşumunda önemli rol oynamaktadır. Ancak eğimli arazilerde mesken yapımı için yapılan kazılar, yol yarmaları, tarım alanı açmak amacıyla ormanların tahrip edilmesi ve meralardaki aşırı otlatma, yerleşmeye açılan akarsu havzalarında ve üzeri kapatılan akarsuların bulunduğu yerleşim merkezleri insan kaynaklı sel, taşkın ve heyelana neden olmaktadır. Kıyıdaki kasaba ve şehir yerleşmelerinin çoğunda akarsu yataklarının üzeri kapatılmıştır. Yerleşim merkezlerinde akarsular için yapılan kanallar ve menfezler şiddetli yağışların görüldüğü zamanlarda yetersiz kalmaktadır. Yüzeysel akışa geçen sular taşıdıkları malzemeleri kanalların ve menfezlerin ağız kısımlarında biriktirerek suların çevreye yayılmasına neden olur. Bu sular konutlara, endüstrilere, ulaşım güzergâhlarına ve tarım alanlarına zarar vermektedir (Kadığlu vd. 2017; Oğuz vd. 2016). Nitekim 2020 ve 2021 yıllarında yaşanan sel ve heyelan olaylarının sonuçları yıkıcı boyutta yaşanmıştır. Ülkemizdeki yerleşim birimlerinin \%25'i en az bir kütle hareketi olayına maruz kaldığı düşünülürse, riskli bölgelerde kaya düşmesi/ heyelan kaynaklı KBRN-p olaylarının yaşanmaması için yerleşim planları buna göre yapılmalıdır.

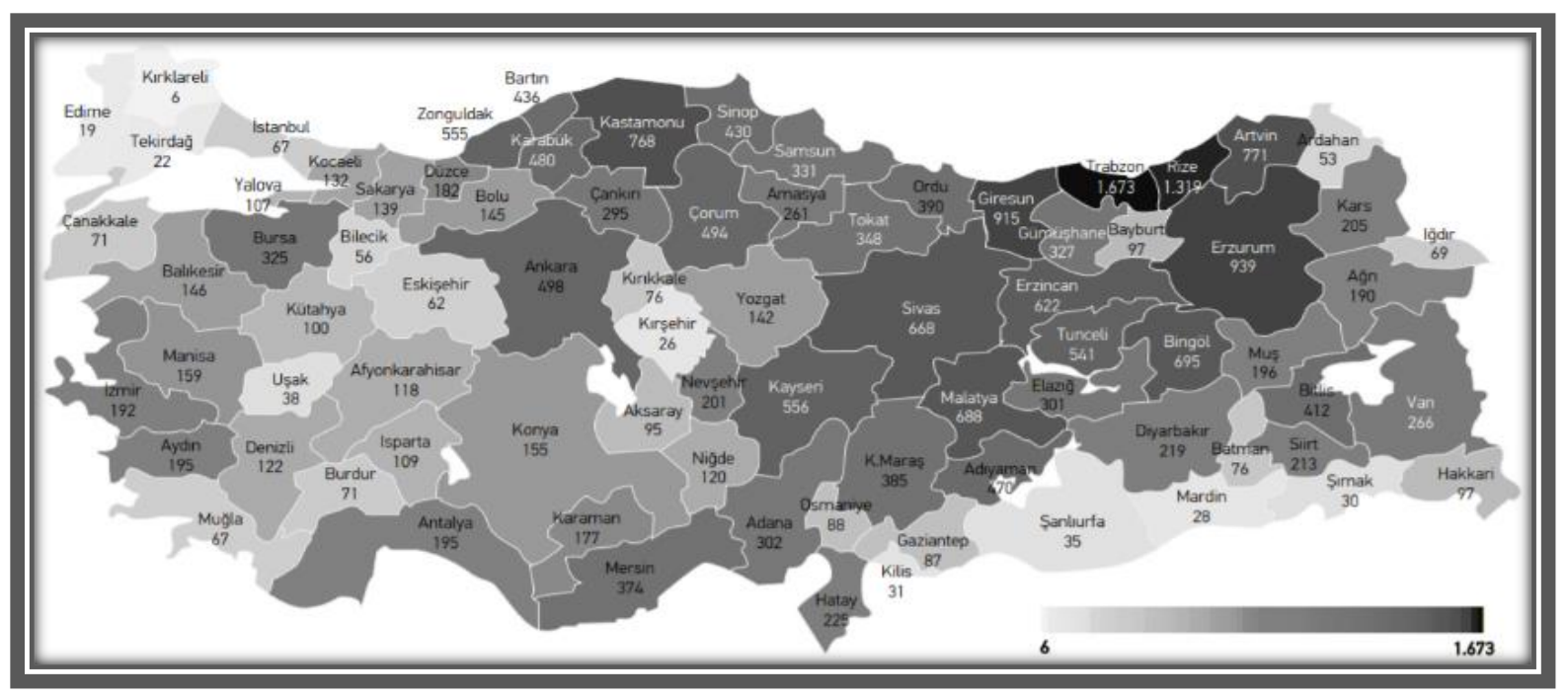

Şekil 10: 1950- 2019 yılları arasında Türkiye'de meydana gelen heyelan/kaya düşmesi olaylarının il bazında sayıları (AFAD 2020)

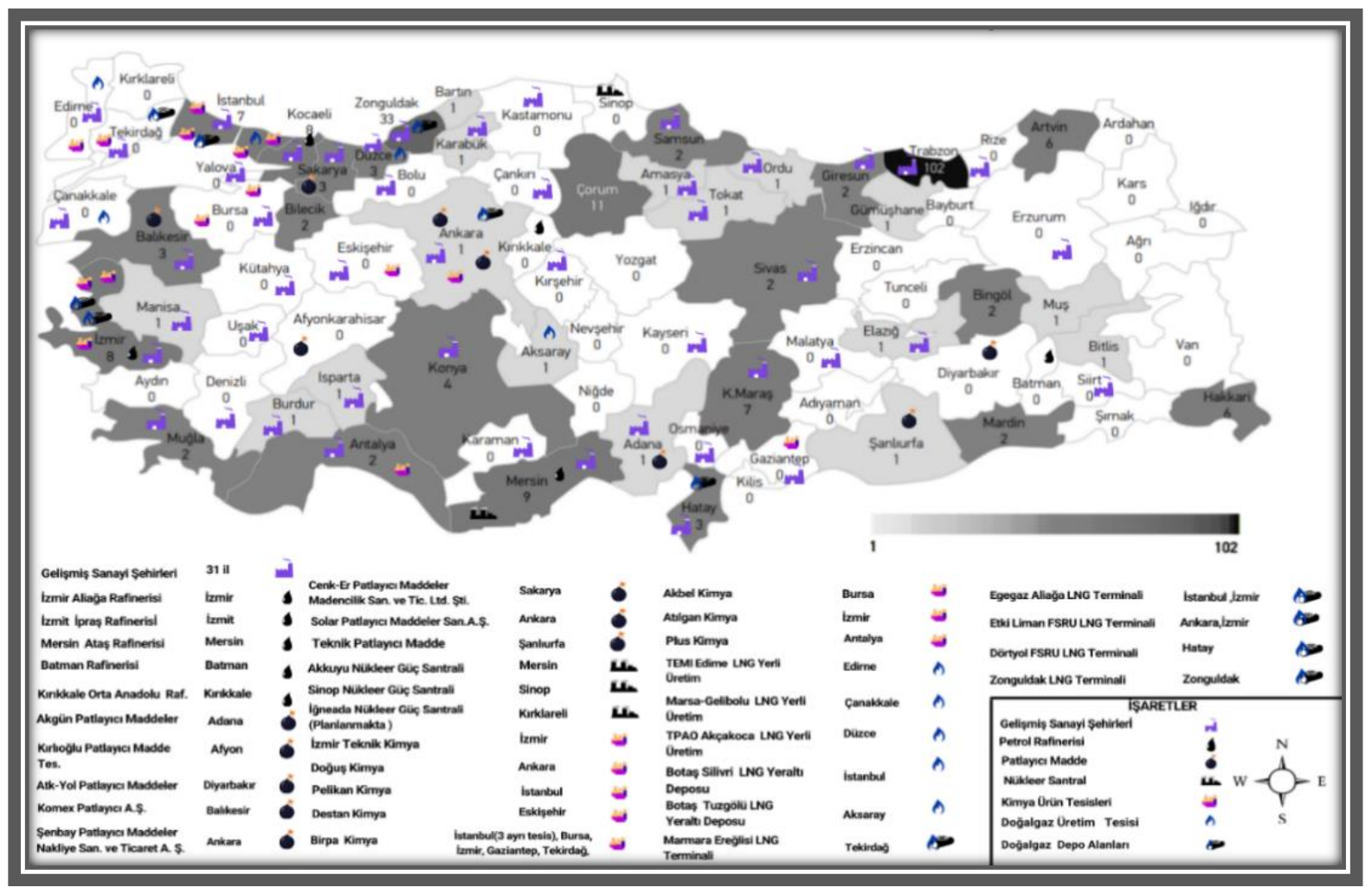

Şekil 11: 2019 yıllında Türkiye'de meydana gelen heyelan/kaya düşmesi olaylarının il bazında sayıları (AFAD 2020) ve $K B R N-p$ riski taşıyan endüstri ve enerji tesisleri 
AFAD (2020), tarafından hazırlanmış olan Türkiye Çı̆̆ Tehlike Haritası, Ülkemizde 1950-2019 yılları arasında yaşanmış çı̆̆ olaylarının verilerinin istatiksel modellemeleri sonucu oluşturulmuştur. Bu yıllar arası meydana gelen çı̆̆ sayısı Şekil 12 'de verilen haritada pembe ve bordo renk arasındaki renk değişiklikleri ile açıktan koyuya doğru artan şekilde gösterilmiştir. İl bazında 2019 yılında meydana gelen çığ sayısının dağılımı incelendiğinde; 4 çığ olayının Kahramanmaraş'ta yaşandığı, Tunceli'de 2, Hakkâri, Artvin, Erzurum ve Van'da da 1 çı̆̆ olayının yaşandığı görülmektedir. Çığ tehlikesinin olduğu bölgelerde muhtemel KBRN-p açısından risk oluşturabilecek endüstri ve enerji tesisleri Şekil 13’te gösterilmiştir.

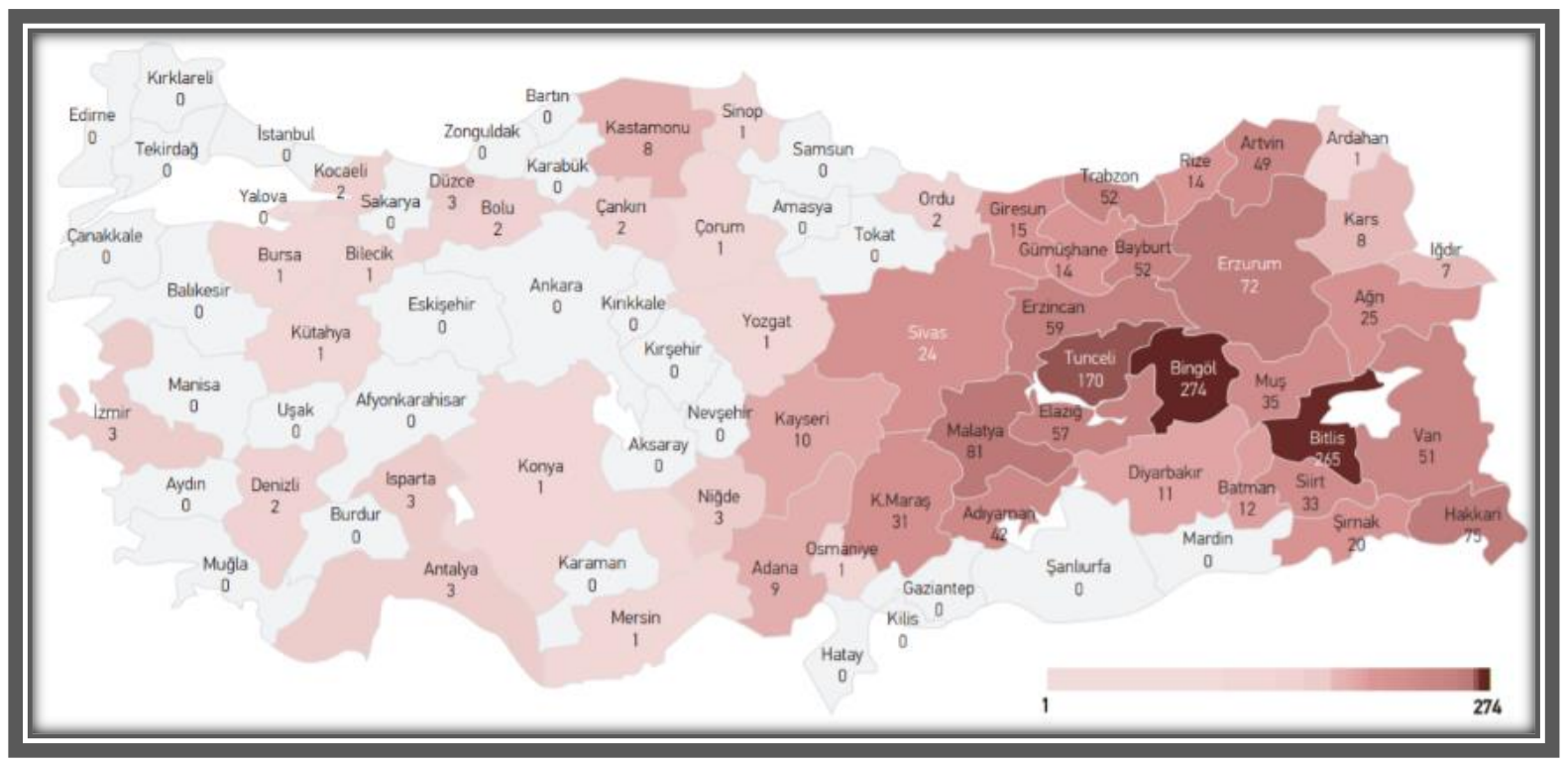

Şekil 12: 1950- 2019 yılları arasında Türkiye'de meydana gelen çığ olaylarının il bazında sayıları (AFAD 2020)

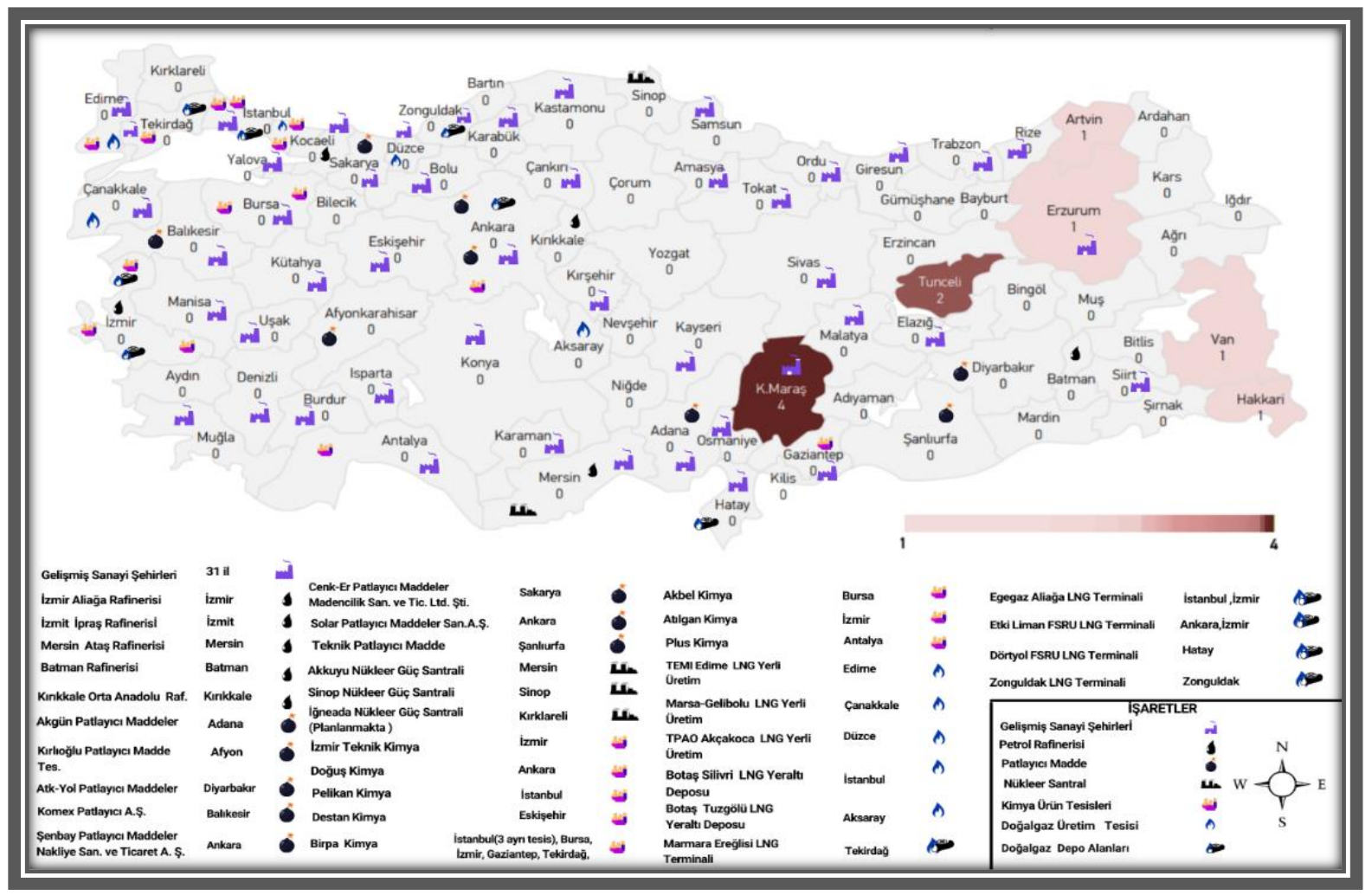

Şekil 13: 2019 yıllında Türkiye'de meydana gelen çığ olaylarının il bazında sayıları (AFAD 2020) ve KBRN-p riski taşıyan endüstri ve enerji tesisleri 
Çevre ve Şehircilik Bakanlığının 2018 verilerine göre ülkemizde büyük endüstriyel kaza riski taşıyan BEKRA kuruluşlarının sayısı 388 adet Üst Seviyeli, 421 adet Alt Seviyeli olmak üzere toplam 809 adettir (ÇSB 2018). BEKRA kuruluşları; rafineriler, kâğıt fabrikaları, boya imalathaneleri, kimyasal tesisler ve birçok endüstriyel ve ticari sektörden oluşmaktadır. Teknolojik Kazalar Bilgi Sistemi’ndeki veri tabanına göre, 1967-2018 yılları arasında BEKRA kapsamındaki kuruluşlar da dâhil 209 kaza İstanbul'da, 93 kaza Kocaeli'nde ve 50 kaza İzmir'de gerçekleşmiştir. Veri tabanında yer alan verilerden de görüldüğ̈̈ üzere, kazaların çoğu İzmir, Tekirdağ, Kırıkkale ve Ankara gibi BEKRA kuruluşlarının yoğun olarak bulunduğu illerde gerçekleşmiştir (IKKV 2020). Küresel iklim krizi yoğunlaştıkça, kıyı ve iç kesimlerdeki topluluklar giderek artan bir şekilde doğal afet riski altındadır. Endüstriyel tesisler ve kritik altyapı, iklim değişikliği koşulları ve doğal tehlikelerin etkisine karşı yetersiz eylem nedeniyle savunmasızdır. Aşırı fırtınalar, orman yangınları, depremler, sıcak hava dalgaları, sel, yükselen deniz seviyeleri ve diğer doğal afetler için yeterince hazırlanılmadığında, KBRN-p olayları tetiklenerek toksik maddelerin salınımına, yangınlara ve patlamalar gibi ardışık bir dizi zarar meydana gelebilmektedir. Tehlikeli ve hatta yıkıcı salınımlar ise potansiyel olarak sağlık etkilerine, çevre kirliliğine ve ekonomik kayıplara neden olmaktadır (Krausmann vd. 2019; EPA 2021).

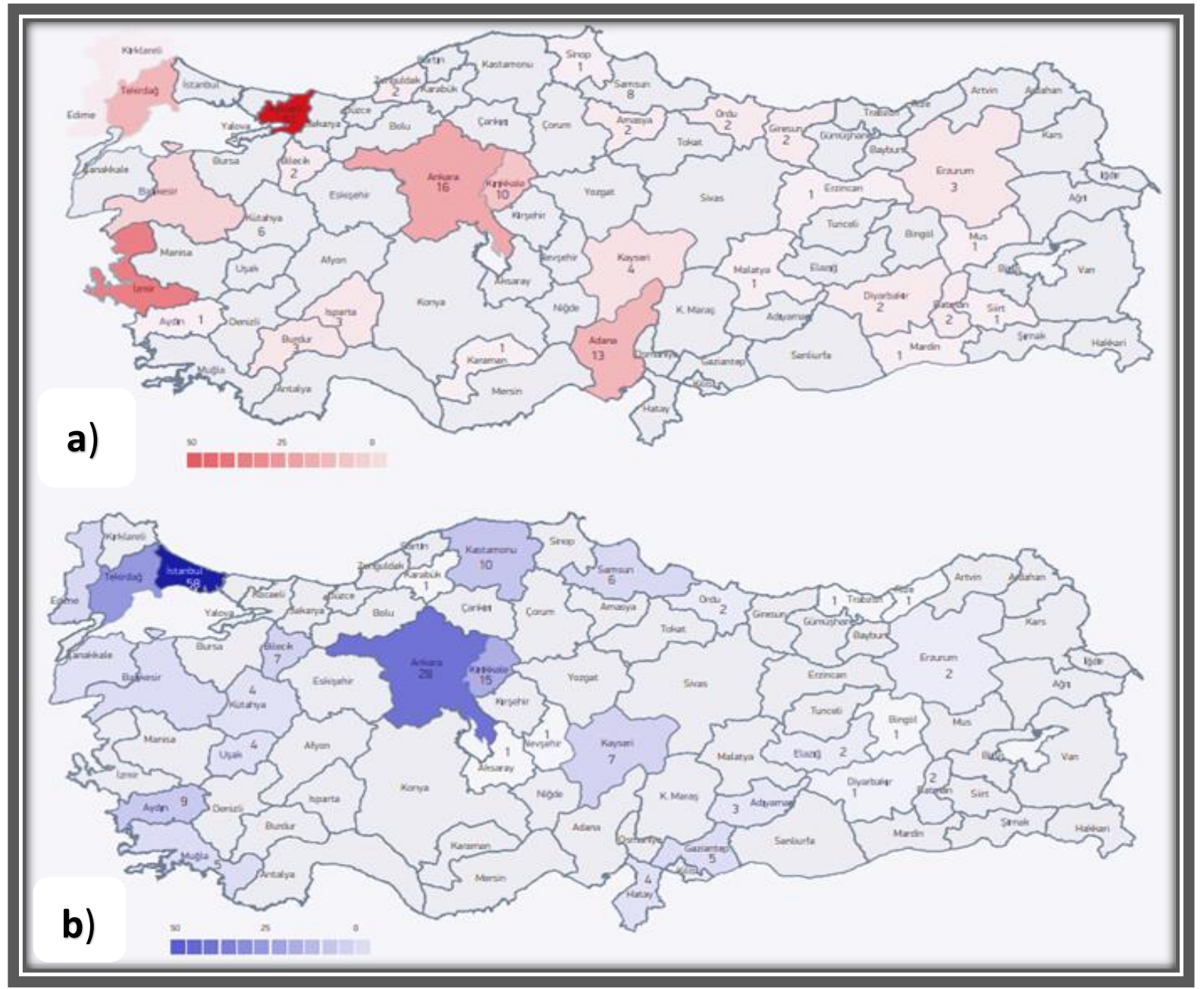

Şekil 14 a) BEKRA kapsamında üst seviyeli kuruluşların illere göre dağılımı (AFAD 2014), b) BEKRA kapsamında alt seviyeli kuruluşların illere göre dağılımı (AFAD 2014)

Modern afetler giderek domino etkisi yaratma eğilimindedir. Doğal acil durumlar hızla KBRN-p tehlikelerinin neden olduğu antropojenik krizlere dönüşebilmektedir. Ardışık afetler bir dizi doğal ve insan kaynaklı tehlikeyi kapsamakta ve ardışık doğaları analizlerini büyük oranda karmaşıklaştırmaktadır. Afetlerin ardışık doğasından dolayı bu durum doğal, ekonomik ve sosyal sistemlerin birbirine bağlılığından ortaya çıkan risk yönetimi için önemli zorlukları ortaya çıkarmaktadır (Felsenstein vd. 2020). Amerika Birleşik Devletleri'ndeki Risk Yönetimi Projesi; kimyasal üreticileri, petrol rafinerileri, su arıtma tesisleri, endüstriyel tarım tesisleri ve kağıt hamuru ve kağıt fabrikaları gibi yaklaşık 12.331 kimyasal tesisi düzenlemektedir. Bu tesislerin yaklaşık üçte biri, iklim değiştikçe çarpıcı biçimde artan orman yangını, fırtına dalgalanması, sel ve deniz seviyesinin yükselmesi risklerine maruz kalmaktadır. Bu, çoğu yerleşim yerlerinin yakınında bulunan yaklaşık 4.000 tesisin daha büyük bir doğal afet tehdidiyle karşı karşıya olduğu anlamına gelmektedir (Şekil 15) (EPA 2021). Doğal afetlere eğilimli bölgelerde tehlikeli kimyasalları ülkemizde de riskli alanların tespiti açısından haritalandırmaların yapılması, kimyasal salınımların kademeli etkilerinden veya sonuçlanabilecek kümülatif ve birleşik tehlikeli maruziyetlerden korumak için başlıca adımlardan biri olmalıdır. 


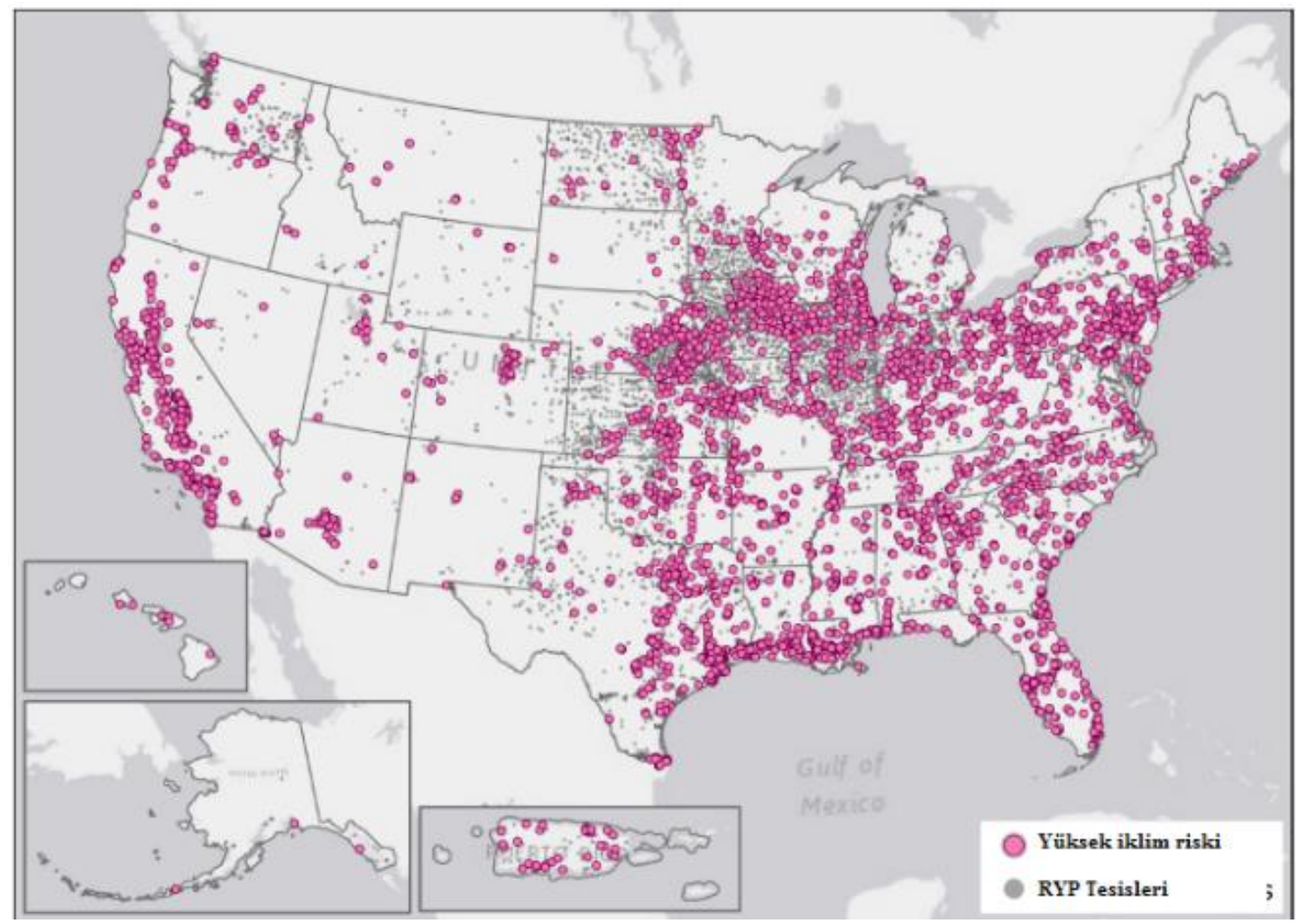

Şekil 15: ABD’nin yüksek iklim riski ve tehlikeli kimyasalları kullanan, depolayan ve/veya yöneten endüstriyel tesis haritası

\section{Tartışma ve Sonuç}

Afetlerin etkin bir şekilde ele alınabilmesi için iklim değişikliği, yerel kırılganlıklar, toplumsal dayanıklılık ve sürdürülebilirlik gibi konuların afet yönetimi sürecinin bir parçası olarak düşünülmesi gerekmektedir. Ardışık afetler kavramı, kritik altyapının bozulmasından kaynaklanan olaylar gibi ikincil acil durumların alevlenmesiyle ortaya çıkan olaylara odaklanan bu sürecin bir parçası olarak görülebilir. Ortaya çıkan etkiler daha çok güvenlik açığının büyüklüğü ile ilişkilidir. Gerektiği gibi ele alınmaması durumunda düşük seviyeli tehlikelerde bile sistemde güvenlik açıklarının yaygın olması ile geniş zincir etkiler ortaya çıkabilmektedir (URL-1 2021).

KBRN-p kaynaklı olaylar da; zincir etkiler oluşturan, karmaşık, çok boyutlu ve zaman içinde sürekli gelişerek fiziksel, sosyal veya ekonomik bozulmayla sonuçlanan bir dizi olayın oluşturduğu durumlardır. Ayrıca bu olaylar sadece bölgesel değil tüm dünyayı tehdit eden dinamiklerdir. Bu nedenle uluslararası güvenlik bağlamında Kimyasal, Biyolojik, Radyolojik, Nükleer ve/veya doğası gereği patlayıcı olan tehlikelerin oluşturacağı risklerin önlenmesi ve azaltılması dünyada önemli bir faaliyet alanı haline gelmiştir (UNDRR 2021b). Avrupa Birliği de bu maddelere ilişkin tehdit ve riskleri azaltmak için uluslararası çabalara önemli katkılarda bulunmaktadır. Seveso Direktifi, AB politikalarıyla iyi bir şekilde entegre edilmiştir. Kimyasalların sınıflandırılması, etiketlenmesi ve paketlenmesi, Birliğin Sivil Koruma Mekanizması, KBRN-p ve Kritik Altyapının Korunması dahil Güvenlik Birliği Gündemi, Çevresel sorumluluk ve çevrenin ceza hukuku yoluyla korunmasına ilişkin politika, Açık deniz petrol ve gaz operasyonlarının güvenliği gibi politika alanlarını içerir (EC 2021).

Ülkemiz en fazla üst ve alt seviyeli Seveso (Ülkemiz mevzuatına göre BEKRA) kuruluşuna sahip beşinci Avrupa ülkesi olarak KBRN-p tehlikeleri ile karşılaşma ihtimali yüksek ülkeler arasındadır. Enerji sektöründe ve büyük endüstrilerde yaşanabilecek kazaları önlemek ve bu kazaların etkilerini azaltmak için Kimyasal, Biyolojik, Radyolojik, Nükleer ve Patlayıcılara yönelik stratejilerin belirlenmesi önem arz etmektedir. Ülkemizde bu kapsamda endüstriyel kazaların risk azaltımına yönelik yasal düzenlemeler BEKRA ile sağlanmıştır (Dökmeci 2008). Ancak yasal düzenlemeler olası bir endüstriyel kazaya yönelik hazırlandığından ardışık afetler göz ardı edilmektedir. Özellikle en fazla alt seviyeli kuruluşa sahip olan İstanbul, Ankara, Tekirdağ, Kırıkkale ve Kastamonu ve en fazla üst seviyeli kuruluşa ev sahipliği yapan İstanbul, İzmir, Ankara, Adana, Tekirdağ ve Kırıkkale illerinde yaşanmış ve yaşanacak doğal olayların tehlike ve riskleri değerlendirilirken ve risk azaltma planları hazırlanırken ardışık afetler göz ardı edilmemeli ve multi tehlikelerin yer aldığı risk yönetimi planlanmalıdır.

KBRN-p olayları, tehlikeli maddelerin salınımı, yangınlar ve patlamalar nedeniyle doğal bir afetin çevre ve insan sağlığı üzerindeki etkisini daha da kötüleştirebilir. Ardışık ve zincirleme yaşanan hem çevresel hem de insan sağlı̆̆ını tehdit edebilecek bu olaylardaki zincirin unsurlarını izole etmek ve onları başı başına bireysel afetler olarak görmek, iklim değişikliği sonucu artan doğal olaylar ile KBRN-p tehlikeleri içeren bir risk yönetimi yaklaşımına entegre etmek ardışık şekilde ortaya çıkabilecek felaketlerin önüne geçmede oldukça etkili bir adım olacaktır. 
$\mathrm{Bu}$ nedenle risk analizlerinin öncesinde yapılarak gereken önleyici tedbirlerin alınması gerekmektedir. Ancak teknolojik veya doğa kökenli tehlikelerden kaynaklanan risklerle başa çıkmak için önleme ve hazırlık önlemleri, müdahale ve kurtarma planlarının entegre edilmesi gerekmektedir. KBRN-p risk analizi ve haritalaması için yöntem ve araçlar eksik olduğundan doğa kaynaklı tehlikelerin olduğu bölgelerde olası bir ardışık afete neden olabilecek KBRN-p olaylarının olma olasılığını içeren planları geliştirmek gerekmektedir.

\section{Kaynaklar}

AFAD, (2014), 2014-2023 Büyük Endüstriyel Kazalar Yol Haritası Belgesi, Afet ve Acil Durum Yönetimi Başkanlığı, https://www.afad.gov.tr/kurumlar/afad.gov.tr/3907/xfiles/endustriyel_kazalar_son.pdf, [Erişim 05 Temmuz 2021].

AFAD, (2018), Türkiye Deprem Tehlike Haritası, Afet ve Acil Durum Yönetimi Başkanlığı, https://www.turkiye.gov.tr/afad-turkiyedeprem-tehlike-haritalari, [Erişim 25 Haziran 2021].

AFAD, (2020), Afet İstatistikleri, Afet ve Acil Durum Yönetimi Başkanlığ 1 , https://www.afad.gov.tr/kurumlar/afad.gov.tr/ e_Kutuphane/KurumsalRaporlar/Afet_Istatistikleri_2020_web.pdf, [Erişim 20 Haziran 2021].

AFAD, (2021), 2020 Yılı Doğa Kaynaklı Olay İstatistikleri, Afet ve Acil Durum Yönetimi Başkanlığı, https://www.afad.gov.tr/ kurumlar/afad.gov.tr/e_Kutuphane/Istatistikler/2020yilidogakaynakliolayistatistikleri.pdf, [Erişim 20 Ekim 2021].

Alexander D.E., (2018), A magnitude scale for cascading disasters, International Journal of Disaster Risk Reduction, 30(B), $180-185$.

Alexander D.E., Pescaroli G., (2019), The role of translators and interpreters in cascading crises and disasters: Towards a framework for confronting the challenges, Disaster Prevention and Management, 29(2), 144-156.

BEKRA, (2019), Büyük Endüstriyel Kazaların Önlenmesi ve Etkilerinin Azaltılması Hakkında Yönetmelik, T.C. Resmi Gazete, Say1:30702, Tarih: 02.03.2019, https://www.resmigazete.gov.tr/eskiler/2019/03/20190302-1.htm, [Erişim 4 Temmuz 2021].

Boin A., Hart P.T., Kuipers S., (2018), The crisis approach, Handbook of Disaster Research'ün İçinde, (Rodríguez H., Donner W., Trainor J.E., Ed.), Springer, Cham, New York, ss.23-38.

Cruz A.M., (2003), Cascading events and hazardous materials releases during the Kocaeli Earthquake in Turkey, Analysis of Natech (Natural Hazard Triggering Technological Disasters), Disaster Management NEDIES Workshop Proceedings Ispra, Italy, ss.20 21.

ÇSB, (2018), Çevre Denetim Raporu, Çevre ve Şehircilik Bakanlığı, https://webdosya.csb.gov.tr/db/ced/icerikler/2018_cevre_denetm_raporu-20190711083900.pdf, [Erişim 05 Temmuz 2021].

Donaldson L., (1991), Coping with Crisis: The Management of Disasters, Riots and Terrorism, Australian Journal of Management, 1681), 99-102.

Dökmeci A.H., (2018), Toksikolojik Çevresel ve Endüstriyel Afetler, Nobel T1p Kitabevi, İstanbul, 210ss.

EC, (2021), Major accident hazards, European Commision, https://ec.europa.eu/environment/seveso/ [Erişim 10 Aralık 2021].

EM-DAT, (2021), Cred Crunch 62 - 2020 Annual Report, Centre for Research on the Epidemiology of Disasters (CRED), https://www.emdat.be/cred-crunch-62-2020-annual-report-0, [Erişim 18 Ekim 2021].

EPA, (2021), Preventing "Double Disasters", Environmental Protection Agency, https://www.ucsusa.org/sites/default/files/202107/preventing-double-disasters\%20FINAL.pdf, [Erişim 25 Ekim 2021].

Ergünay O., (2009), Afet Yönetimi Genel İlkeler, Tanımlar, Kavramlar, Afet İşleri Genel Müdürlügü, Ankara.

EU, (2021), Overview of natural and man-made disaster risks the European Union may face, https://op.europa.eu/en/publicationdetail/-/publication/285d038f-b543-11e7-837e-01aa75ed71a1, [Erişim 05 Haziran 2021].

Felsenstein D., Shmueli D.F., Thomas D.S.K., (2020), Cascades - Mapping the multi-disciplinary landscape in a post-pandemic World, International Journal of Disaster Risk Reduction, 51, 101842, doi: 10.1016/j.ijdrr.2020.101842.

Girgin S., Krausmann E., (2013), Mapping Natech risk due to earthquakes using RAPID-N, Geophysical Research Abstracts, Vol. 15, EGU2013-1246, EGU General Assembly.

IFRC, (2020), World Disasters Report 2020, https://www.ifrc.org/sites/default/files/2021-09/20201113_WorldDisasters_4.pdf [Erişim 14 Ekim 2021].

İKV, (2020), Sanayi-Çevre İlişkisi: AB ve Türkiye'de Büyük Endüstriyel Kazaların Önlenmesi Yönergesi, İktisadi Kalkınma Vakfi, https://www.ikv.org.tr/images/files/AB\%20ve\%20T\%C3\%BCrkiyede\%20B\%C3\%BCy\%C3\%BCk\%20End\%C3\%BCstriyel\%20 Kazalar\%C4\%B1n\%20\%C3\%96nlenmesi\%20Y\%C3\%B6ndergesi.pdf, [Erişim 26 Haziran 2021].

Kadıoğlu M., (2011), Afet Yönetimi Beklenilmeyeni Beklemek, En Kötüsünü Yönetmek, Afet Tanımları, Marmara Belediyeler Birliği Yayını, Yayın No: 65, İstanbul, 220ss.

Kadığlu Y, Bağcı H.R., Yılmaz C., (2017), Doğu Karadeniz Kıyı Kuşağındaki Doğal Afetlere Bir Örnek: 21 Eylül 2016 Tarihli Beşikdüzü seli ve heyelanları, Marmara Coğrafya Dergisi, 36, 232-242.

Krausmann E., Girgin S., Necci A., (2019), Natural hazard impacts on industry and critical infrastructure: Natech risk drivers and risk management performance indicators, International Journal of Disaster Risk Reduction, 40, 101163, doi: 10.1016/j.ijdrr.2019.101163.

May F., (2007), Cascading disaster models in postburn flash flood, USDA Forest Service Proceedings RMRS-P-46C, 26-30 March, Destin, FL., ss.443-464.

Oğuz E., Ulupınar Y., Oğuz K., Aksoy M., Akbaş A.İ., Köse S., Çelik S., (2016), Artvin-Hopa Bölgesinde Meydana Gelen Taşkın ve Heyelan Olayinin İncelenmesi, Ulusal Heyelan Sempozyumu, 27-29 Nisan, Ankara, ss. 531-550.

Pescaroli G., Alexander D.A., (2015), A definition of cascading disasters and cascading effects: going beyond the "Toppling Dominos" metaphor, Planet and Risk, 3(1), 58-67.

Pescaroli G., Kelman I., (2017), How Critical Infrastructure Orients International Relief in Cascading Disasters, Journal of Contingencies and Crisis Management, 25(2), 56-67.

Quarantelli E.L., (2005), A social science research agenda for the disasters of the 21st century: Theoretical, methodological and empirical issues and their professional implementation, What is a disaster?, 325-396.

TDK, (2015), Genel Açıklamalı Sözlük, Türk Dil Kurumu, TDK Yayınları, Ankara.

UNDRR, (2007), Hyogo framework for action 2005-2015: Building the resilience of nations and communities to disasters, United Nations Office for Disaster Risk Reduction, https://www.undrr.org/publication/hyogo-framework-action-2005-2015-buildingresilience-nations-and-communities-disasters [Erişim 19 Ekim 2021]. 
UNDRR, (2015), Sendai framework for disaster risk reduction 2015-2030, United Nations Office for Disaster Risk Reduction, https://www.undrr.org/publication/sendai-framework-disaster-risk-reduction-2015-2030 [Erişim 19 Ekim 2021].

UNDRR, (2021a), Preparing for disasters and emergencies, The United Nations Office for Disaster Risk Reduction, https://www.preventionweb.net/files/8450_gprch1618.pdf [Erişim 10 Aralık 2021].

UNDRR, (2021b), Disaster risk, The United Nations Office for Disaster Risk Reduction, https://www.undrr.org/terminology/disasterrisk [Erişim 19 Ekim 2021].

UN/ISDR, (2004), Disaster risk reduction for sustainable development in Africa, Guidelines for mainstreaming disaster risk assessment in development, https://www.humanitarianlibrary.org/sites/default/files/2014/02/UNISDR_DRR4Sustainable DevelopmentInAfrica.pdf, [Erişim 19 Ekim 2021].

URL-1, (2021), International efforts for industrial and chemical accidents prevention, preparedness and response, https://www.oecd.org/chemicalsafety/chemical-accidents/Brochure\%20chemical\%20accidents\%20prevention,\%20preparedness \%20and\%20response.pdf [Erişim 17 Kasım 2021].

Zuccaro G., De Gregorio D., Leone M.F., (2018), Theoretical model for cascading effects analyses, International Journal of Disaster Risk Reduction, 30(Part B), 199-215. 